The emergence of a knowledge-intensive sector in Portugal: social networks and innovation in the software sector

Isabel Salavisa

Pedro Videira

Cristina Sousa

2011

WP no 2011/13

DOCUMENTO DE TRABALHO

WORKING PAPER

DINAMIR'CET

CENTRO DE ESTUDOS SOBRE A MUDANCA
SOCIOECONOMICAE O TERAITORIO

ISCTE-IUL

FCT

Fundaçio para a Ciência e a Tecrologia 
The emergence of a knowledge-intensive sector in Portugal: social networks and innovation in the software sector ${ }^{1}$

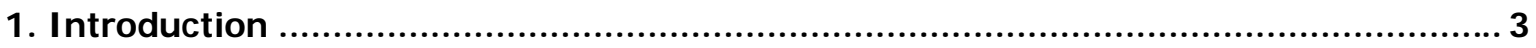

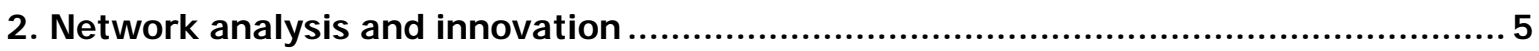

3. Software for telecommunications in Portugal................................................................ 8

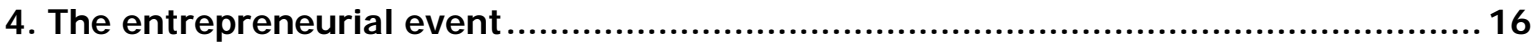

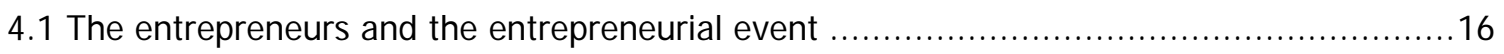

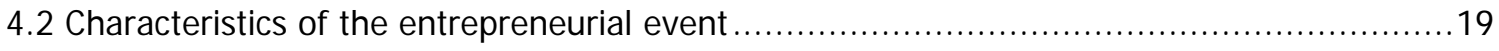

5. Social networks and the entrepreneurial event.......................................................... 20

5.1 The importance of networks in the start-up stage ........................................... 20

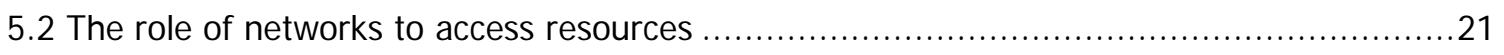

6. The contribution of social networks to innovative achievements ............................ 24

6.1 Entrepreneurs' profile, network configuration and innovative performance ......................24

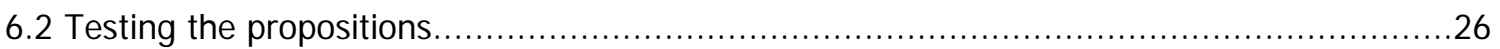

6.3 In search of an overall explanation of innovation in the software for telecommunications

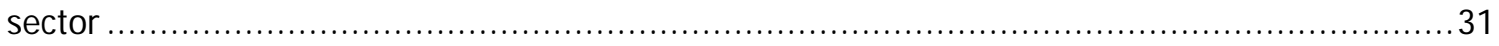

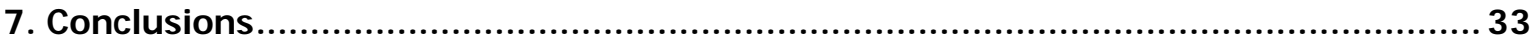

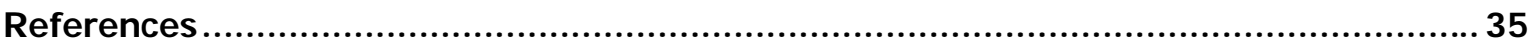

${ }^{1}$ This paper draws on the research carried out within the Project ENTSOCNET - Social networks, entrepreneurs and access to knowledge: the case of biotechnology and the IT industries, funded by FCT - Fundação para a Ciência e a Tecnologia (POCl/ESC/60500/2004), Portugal. The results will be published in a book edited by I. Salavisa and M. Fontes (2012), "Social Networks, Innovation and the Knowledge Economy", Routledge.

* DINÂMIA'CET-IUL and Instituto Universitário de Lisboa (ISCTE-IUL), Lisbon, Portugal.

* DINÂMIA'CET-IUL, Lisbon, Portugal. 



\title{
The emergence of a knowledge-intensive sector in Portugal: social networks and innovation in the software sector
}

\begin{abstract}
This paper deals with the development of the software for telecommunications sector, a relatively small segment in the global software industry though one of its most innovative. In fact, its products address the demand of one of the most sophisticated and fastest changing industries today, the telecommunications industry. We attempt to explain how and why this sector has evolved in Portugal since its inception in the early 1980s.

Social networks have played a relevant role in this entrepreneurial and innovative process, both for the formation and early stage development of firms. We will analyse the relevance and type of the networks involved in the process, before investigating the existence of an association between their composition and the innovative patterns of the firms, in terms of more radical versus more incremental innovation. This implies taking into account the intra-sector diversity, namely the existence of distinct groups of firms within the sector, in relation to their innovative strategies and capabilities. Finally, we will draw some conclusions and discuss policy implications.
\end{abstract}





\section{INTRODUCTION}

This paper deals with the development of the software for telecommunications sector, a relatively small segment in the global software industry though one of its most innovative. In fact, its products address the demand of one of the most sophisticated and fastest changing industries today, the telecommunications industry, with mobile communications at its core. We attempt to explain how and why this sector has evolved in Portugal since its inception in the early 1980s.

The sector's creation was made possible by the combination of several major factors of a diversified nature: entrepreneurial capability; high quality engineering schools; very competitive telecommunications services; the presence and strategies of multinational corporations; dramatic technological changes in relevant technologies; and profound societal shifts. While some of these factors are undoubtedly general, others appear to be country-specific.

Social networks have played a relevant role in this entrepreneurial and innovative process, both for the formation and early stage development of firms. This is because of: the technology used; the need for complementary assets; the size of the firms; their strategies; the kinds of customer; and, in intermediate innovative contexts, to substitute for missing links.

As to technological knowledge, networks have long been identified as a key factor in high technology sectors since knowledge has become complex and fast changing and is distributed among various players (Powell and Grodal, 2005:59). In the case of software, firms have to interact not only with other domestic and multinational firms in the same sector (Grimaldi and Torrisi, 2001; 1431), and universities, but also with customers, the latter being the major source of innovation (Weterings and Boschma, 2009: 749).

Complementary assets (Teece, 1986) such as capital, information on potential opportunities and highly qualified personnel have become increasingly specialized and sophisticated. Such resources are not totally obtainable through anonymous and stand-alone market transactions. Their access requires interaction, trust and information exchange (Powell and Grodal, 2005).

Small firms are less able to create and develop in-house the range of knowledge and skills required to succeed. They tend to be specialized in a limited range of technologies and/or goods and then to look for partnerships or explore a niche.

Moreover, firms in these sectors deploy strategies to compete on the basis of technological novelty, continuous improvement and differentiation. They become high technology firms not only because 
of the nature of their knowledge base but also because this represents a means to reinforce their competitive weapons (Grimaldi and Torrisi, 2001; Aramand, 2008; Tsang, 2005).

The driving forces towards innovation may be found in the types of customer of software firms. Their customers tend to be companies that want their products to embody sophistication or need to resolve difficult technological problems to launch new products. They also depend on technology that is in no way packaged, embodied and standardized. On the contrary, they rely on technology under construction, that is tailor made and for which interaction is necessary. Problem solving is part of this game and involves both the customer and the supplier. We know from the literature that innovation in software is driven by customers' demands and users' needs (Aramand, 2008:157 and Weterings and Boschma, 2009:749).

Finally, countries or regions with a lack of large domestic hardware firms must deploy connections with other types of customer and technology supplier. Unlike the US (Steinmueller, 1996), this is the case of the European software industry which has suffered from a combination of a weak hardware sector and the early entry of American software firms (Campbell-Kelly, 1995; Malerba and Torrisi, 1996).

In some countries, overseas relationships as well as the presence of multinational corporations' affiliates became more important. The spill-overs of multinational companies to the domestic economy may take different forms: demonstration effects via proximity and contractual relationships; labour mobility; competition effects; reputation effects; and incubators of spin-off firms (Giarratana, Pagano and Torrisi, 2004). They have played a relevant role in the upsurge and development of a domestic software industry in countries such as Ireland where the industry was at an incipient stage prior to their entry (idem). But their role may also have been complementary when they entered after the creation of a local industry, as seemed to be the case in India and Israel (idem).

In all cases, however, small companies have to diversify their relations when the country has no large IT firms with R\&D facilities. The latter, specifically those belonging to the computer hardware industry, have played an enormous role in stimulating the creation and deployment of a world class software industry (Malerba and Torrisi, 1996; Steinmueller, 1996; Cloodt, Hagedoorn, and Roijakkers, 2010). Furthermore, innovation in software has also been driven because there is a competitive computer industry. Aramand mentions electronics, computing hardware and telecommunication industries as the main external driving forces of change in software, notably computing hardware (2008:157). 
These firms have to resort to universities for resources other than knowledge. Universities are usually cited as the source of highly educated employees (Weterings and Boschma, 2009) but also for the interaction of tacit knowledge (Tsang, 2005).

This is where networks appear in the picture. Their prominence is not only a novel conceptualization of old relations, but also the expression of new phenomena connected to turbulent and sophisticated technologies, the existence of a knowledge based society and the increased segmentation and specialization of industries. In addition, they allow aspects to be uncovered that were hitherto veiled by the conventional view of market transactions versus intraorganizational relations.

In this paper, we will briefly present the main traits of the software industry in Portugal and identify the causes underlying the changes made, the actors in this process and their shared relations, with a focus on software for telecommunications. We will start by presenting our theoretical background, namely regarding the role of networks in the innovation process. Then we will introduce the software for telecommunications sector, its main features and the way it has evolved and then present the firms and entrepreneurs. We will then address the relevance and type of social networks involved in the process, before investigating if their specific configuration is associated with the type of innovativeness achieved by the firms. This implies taking into account the intra-sector diversity, namely the existence of different groups of firms within the sector, in relation to their innovative strategies and capabilities. Finally, we will draw some conclusions and discuss policy implications.

\section{NETWORK ANALYSIS AND INNOVATION}

Networks consist of a way of modelling social structures. Scott writes that "social network analysis is an orientation towards the social world that inheres in a particular set of methods. It is not a specific body of formal or substantive social theory.” (2000:37). As such, their potential application is presumably quite broad. Social network analysis is a powerful tool to analyze social relations, and was founded in the 1960s drawing on the work of social anthropologists and social psychologists over the 1930s. First social network studies were focused on small communities, on kinship relations or work relations.

A vast literature has developed since, but it was not until the 1990s that it began being extensively used to study economic phenomena such as entrepreneurship (see Sousa, 2008, for a review of the literature), innovation and scientific knowledge creation and diffusion. 
The main reasons underlying this development of network analysis are both theoretical and factual. Theoretical reasons encompass the need to incorporate systematic contextualization of human agency and social and economic phenomena, and to adopt systemic approaches. Factual reasons concern the observed real phenomena, and include the need to deal with complex processes and to overcome the shortfalls of increased scientific specialization.

The contextualization reason refers to the acknowledged necessity to study human agency and social phenomena within their context, meaning that no single social entity exists without and outside its social relations. A case in view is the firm, and a new generation of studies on the subject. A second case regards the entrepreneur, its standing and role in economic theory (see Hébert and Link, 1989; Grebel, Pyka and Hanusch, 2003; Granovetter, 1985, and the assertion of embeddedness). Another aspect of the relational context provided by the networks approach is that it takes into consideration the "threads of continuity linking actions across a field of action that includes individuals, organizations, and environment as a totality” (Dubini and Aldrich, 1991:306).

Among factual reasons, stands the increased specialization, which has become a common trait to most human activities and, in a way, is as much a cause as a consequence of economic progress (via productivity and wealth growth), social progress (via better medical services, for instance), scientific and technological advances, sports performances and so on. At the business level, specialization has both permitted and required the spread of companies' networks (see Williamson, 1975).

Technological breakthroughs have permitted, together with transformations in the markets, a reorganization of companies, increasingly focused on their core business and resorting intensively to the outsourcing of services and goods. Large companies have split their operations and partially delocalized them to other regions or countries. Their different sites are connected by internal networks and outwards to suppliers and customers. Almost all have engaged in increased interactions with suppliers, customers, competitors, public agencies, universities and research centres, technological experts, business services, finance companies - and the worldwide web. This "back to the marketplace" trend entails a bigger exposure to uncertainty and to opportunism, both present in market transactions (see Coase and Williamson). The establishment of long-term relations based on predictability and mutual trust could help lessening those problems (see Dubini and Aldrich, 1991).

In short, network analysis could then be a tool to help shedding light on economic phenomena, such as company studies, entrepreneurship, innovation and the creation of knowledge. 
In social networks analysis, the network members are designated by actors or nodes. In this respect, networks can be personal or inter-organizational. Personal networks are composed of individuals, like family, friends and acquaintances (Barnes, 1972; Wellman, 2007). Inter-organizational networks depict relations between organizations, for example, relations between a company and its customers, suppliers, government agencies, universities and research institutes, etc. (Ozman, 2009).

Ties (links, relations) represent relationships between actors and involve a content. The content of a tie can be associated to the communication or transmission of information in symbolic form or the transfer of resources (information, knowledge, materials, money, people, support, prestige and reputation).

In the case of entrepreneurship this content consists of resources and the activities performed to access and mobilize them. Access to different types of resources may involve networks with diverse configurations. To acknowledge this fact, drawing on Castilla et al. (2000) we consider three different resource networks. The "opportunity and access” (O\&A) network is composed of all the actors/relationships used to identify the opportunity and to access and acquire the tangible resources (capital, human resources and facilities) necessary to explore it. The "knowledge network" includes actors/relationships used to obtain scientific and technological knowledge and ideas for innovation. The "power and influence" (P\&I) network is related with the use of well positioned and influential individuals as mediators in the access to key sources of resources/competences and credibilisers towards key actors who could not be mobilized without proper references.

The ties can also be characterized according to the type of interaction. They can either be informal interactions or formal interactions. Formal networks are related with a formal/codified agreement between actors (that usually involves a system of authority, distribution of competences, rights and duties and a device of conflict resolution) and informal networks are more spontaneously created, being frequently associated with personal ties, that are directly mobilized or act as mediators.

Other important perspective of tie characterization is related with the distinction between strong and weak ties and their respective effects on the process of resource mobilization. This stream of research draws on Granovetter $(1973,1982)$ work on the role of social networks in obtaining employment. Strong ties are related with higher levels of reciprocity, trust and social proximity. However, the development and maintenance of this type of ties entail considerable costs (in terms of time and money), and thus actors tend to limit their number. Also, the author's concludes that 
new information is more easily obtained through casual acquaintances (weak ties) than through strong ties. And this is the origin of the "strength of weak ties".

Finally, ego networks consist of a focal actor ("ego") and the actors to whom he is directly connected to ("alters"). Aggregate networks emerge from the aggregation of several ego-networks.

\section{SOFTWARE FOR TELECOMMUNICATIONS IN PORTUGAL}

The software industry in Portugal dates back to the 1960s when some companies began providing computer services to financial companies, government departments and some other large companies, often in conjunction with other business services. This situation is similar to some other countries that had no local computing industry other than the affiliates of multinational companies at the time. In the Portuguese case, these affiliates were looking largely for cheap and unskilled labour to assembling operations. Their role in the emergence of the sector was therefore negligible.

Later, an enormous development took place in the software industry with the microelectronics revolution and the upsurge of the first generation personal computers from the turn of the 1970s to the 1980s. In fact, there was a vast increase in programming abilities, professionals and software houses following the generalization of computing equipment, thanks to the new type of machines.

The generalization of user friendly operative systems and the entry of large packaged software companies like Microsoft on the market entirely changed the use of personal computers and later their portable successors. Formerly, actual users had to write their own software, but now it was embedded in the computer or most of it could be bought by common users.

Packaged software for the general public has never been a success story in Europe. American companies conquered most of the mass markets, while European software houses avoided direct confrontation by turning to software solutions and services for large and small businesses. In the Portuguese case, they followed their European counterparts.

The rise of the Internet and mobile communications in the 1990s brought a new turn. Internet triggered an unprecedented popularization of computers usage, while mobile communications opened up a new domain of technological innovation at a very rapid pace, thus reaching a huge mass market and requiring ever improving software to ensure problem solving and create and maintain continuous novelty. The subsequent interconnection of the two areas originated a cumulative process of innovation. 
It is interesting to note that both mobile phone producers and mobile communications operators were working in the domain to introduce new functionalities in the equipment and services provided or to drastically improve the existing ones. This created an enormous opportunity for the emergence of innovative software start-ups aimed at inventing software modules to be embedded in the equipment, on a self initiative basis or on demand from a customer. It is precisely at this point that our story begins.

The firms we study have benefited from the creation of this new technological market and simultaneously from the existence of very competitive domestic mobile communications operators by any international standard.

Multinational affiliates have also played a role in the development of this sector in a number of ways, namely by hiring their own teams of software developers in the country and by outsourcing or requiring formal partnerships with domestic software houses. Furthermore, they occasionally acquired a few small companies to obtain their competencies and products.

In this context, the roughly 50 Portuguese companies producing software for telecommunications, often as a subsidiary activity, have gradually been identified.

Not all companies were equally relevant to us, considering the relative importance of software for telecommunications within their portfolio of activities and other criteria such as size, market share, technological sophistication and diversity. The target group therefore did not exceed 40 firms; we conducted interviews with 27 of these and gathered information through detailed semi-structured questionnaires on both the firms and the entrepreneurs. Consequently, and with a few exceptions, we managed to cover all major domestic players in the business ranging from small and young firms to large and well established ones.

Small and medium sized companies predominate in our sample - 65\% have less than 50 employees and the average number of workers is 69 (Table 1 and Figure 1). Two companies have over 250. Still in terms of size, around $48 \%$ had a turnover (in 2007) of between $€ 1$ million and $€ 5$ million. The average turnover was $€ 9.5$ million. Three companies had sales of over $€ 25$ million and one of these over $€ 50$ million (Table 2). Taking both criteria, there are 3 large companies in the sample. These companies, and many smaller ones, have a diversified portfolio of activities which means that producing software for telecommunications is just a part of their business. 
As for equity, half of the companies are held by 1 or 2 partners, while 23\% have 6 shareholders or more. For $44 \%$ of the firms, total equity is less than $€ 100,000$ and total equity exceeds $€ 1$ million for only 4 companies (16\%).

FIGURE 1 - Size of the firms

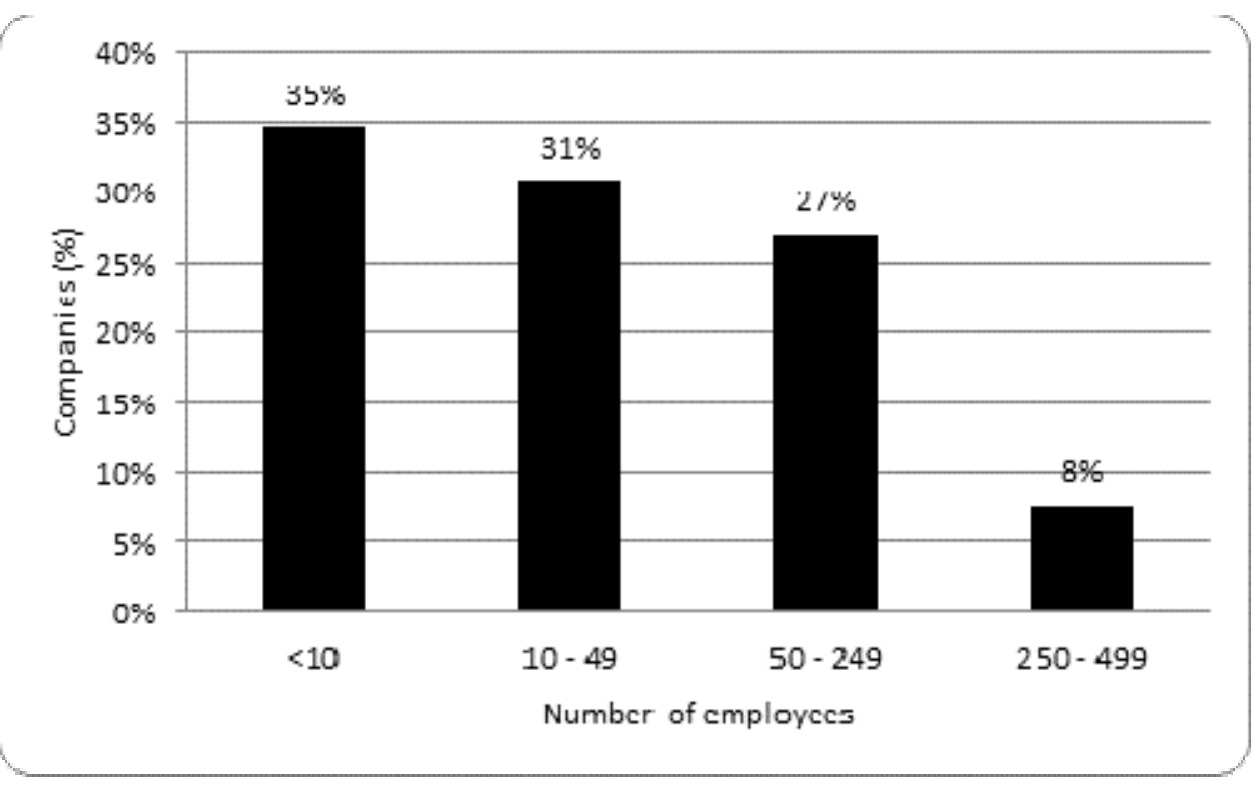

Table 1 - Number of employees and PhDs

\begin{tabular}{lc}
\hline & Number and valid percentage of companies \\
\hline Number of employees & $9(34.6)$ \\
$<10$ & $8(30.8)$ \\
$10-49$ & $7(25.9)$ \\
$50-249$ & $2(7.4)$ \\
$250-499$ & $26(100.0)$ \\
Total & 1 \\
NA & 69 \\
Average number of employees & \\
Companies employing PhDs & $19(82.6)$ \\
Without & $4(17.4)$ \\
With & $23(100.0)$ \\
Total & 4 \\
NA & 1.0 \\
Average percentage of PhDs in total & \\
employees
\end{tabular}


Table 2 - Turnover 2007 (€)

\begin{tabular}{lc}
\hline & $\begin{array}{c}\text { Number and valid percentage of } \\
\text { companies }\end{array}$ \\
\hline 0 & $0(0.0)$ \\
] $0-100,000]$ & $2(8.7)$ \\
] $100000-1,000,000]$ & $5(21.7)$ \\
] $1,000,000-5,000,000]$ & $11(47.8)$ \\
] 5,000,000-25,000,000] & $2(8.7)$ \\
] 25,000,000-50,000,000] & $2(8.7)$ \\
$>50,000,000$ & $1(4.3)$ \\
Total & $23(100.0)$ \\
NA & 4 \\
Average turnover $(2007)$ & $€ 9,500,000$ \\
\hline
\end{tabular}

Turning to age, almost all companies (93\%) were set up from 1991 (Figure 2), with the oldest dating back to 1988. As expected, they are located in metropolitan areas, mainly in the Greater Lisbon area (52\%), but also in the Central region (30\%) - in medium sized cities like Aveiro, Coimbra and Leiria - and in the North (18\%).

FIGURE 2 - Year of formation

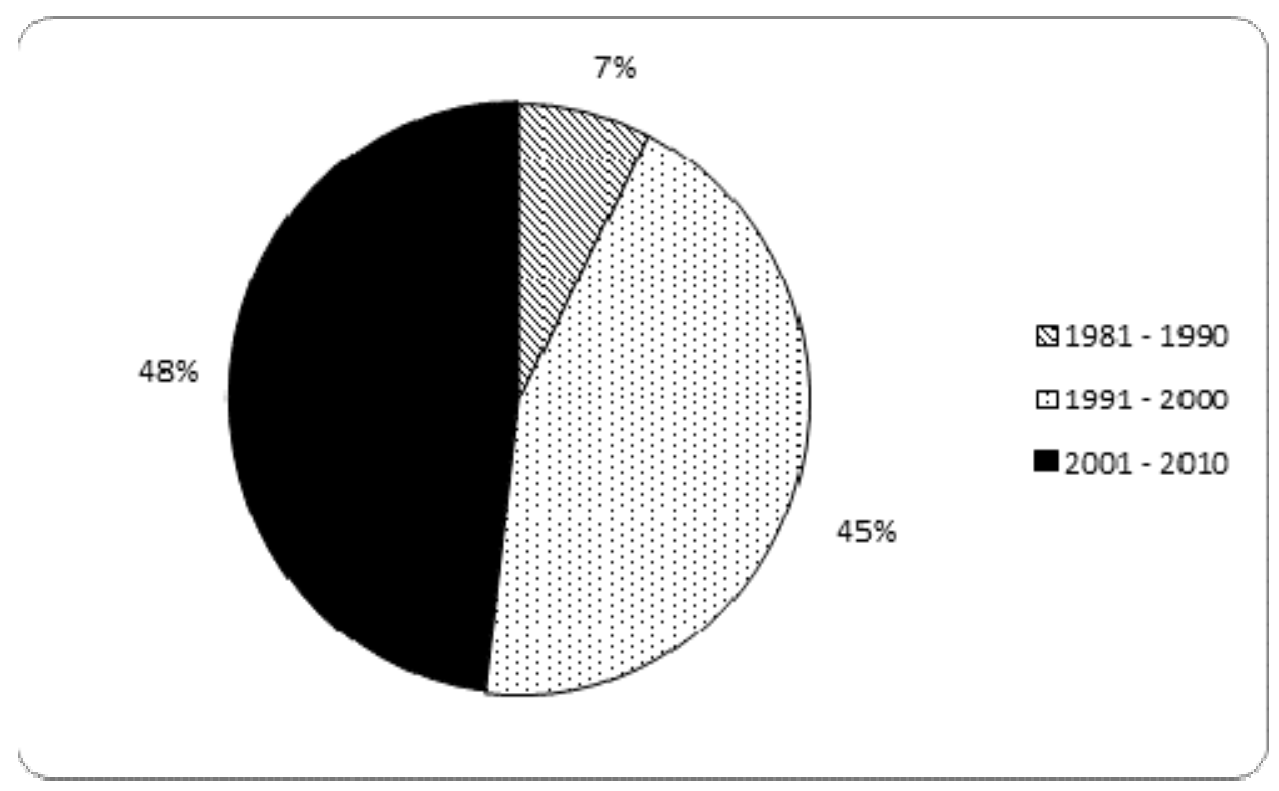

Spin-offs represent more than half of the firms. In fact, ten of the 27 companies (37\%) are research spin-offs, namely companies whose products are based on research carried out by their founders in universities and other research organizations, while 6 (22\%) are traditional corporate spin-offs. 
It is noticeable that $35 \%$ of the respondents refer to the focus on customers as the main concern of their commercial strategy, while the development of new products/processes/partnerships is the predominant concern for 31\%. The 23\% mentioned both aspects (Figure 3). This confirms the prime role of customers to create innovation in the software industry, in general, and in this specific type of software firms, in particular, as mentioned by the literature (Aramand, 2008:157 and Weterings and Boschma, 2009:749).

FIGURE 3 - Commercial strategy

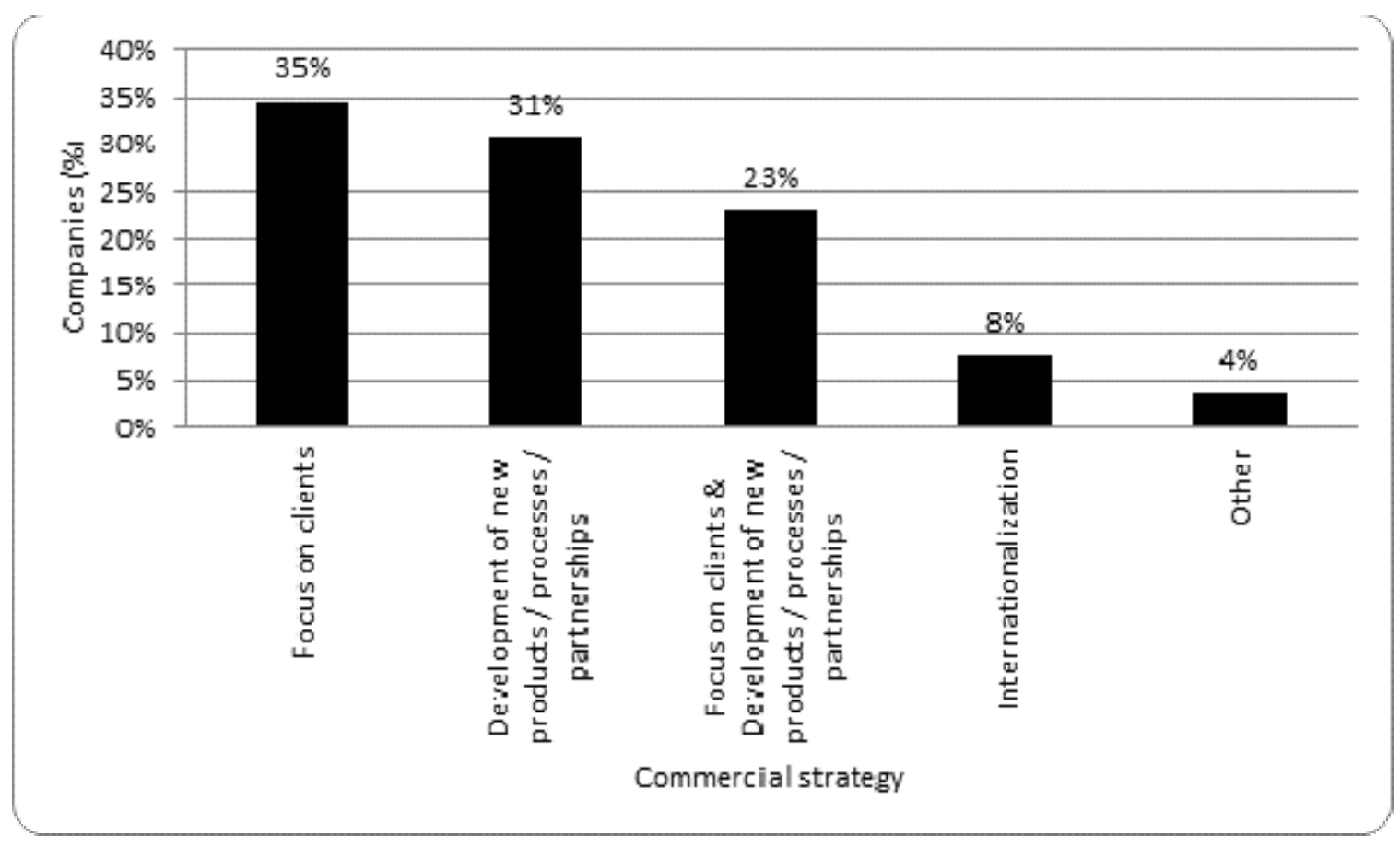

But this might also suggest that most companies are well established in the market, and have already achieved a mature stage. Consequently, they seem to be mostly oriented to expanding their market share by focusing on their clients' needs and demands.

In addition, 19 companies (70\%) describe increasing turnover as a very important strategic objective for the next three years, while the remaining 8 companies (30\%) consider it as a moderately important priority. About $60 \%$ of the companies describe the improvement of their current products and the launching of new ones as very important. All companies consider the entrance in new markets either as a very important (56\%) or moderately important objective (44\%). The increase of exports and client diversification are also regarded as important objectives. These results confirm the strong market and commercial focus of the software for telecommunications companies. 
Furthermore, the major target for the companies is to increase turnover, followed by launching new or improving current products (Figure 4). In fact, growth and product innovation or improvements are intimately linked in this industry (Aramand, 2008). This is also in line with the studies in other countries, since the proliferation and differentiation of products together with continuous technological evolution appear as a prerequisite for firms' development in the software industry. As Giarratana claimed in his paper on the encryption software industry, proliferation is a dominant strategy alongside the tailoring of products to customer preferences in a sector characterized by low entry barriers (Giarratana, 2004:799, who refers to Lancaster, 1990). This argument applies well to the segment studied where continuous product differentiation and niche strategies seem to prevail.

FIGURE 4 - Perceived importance of strategic objectives for the next three years

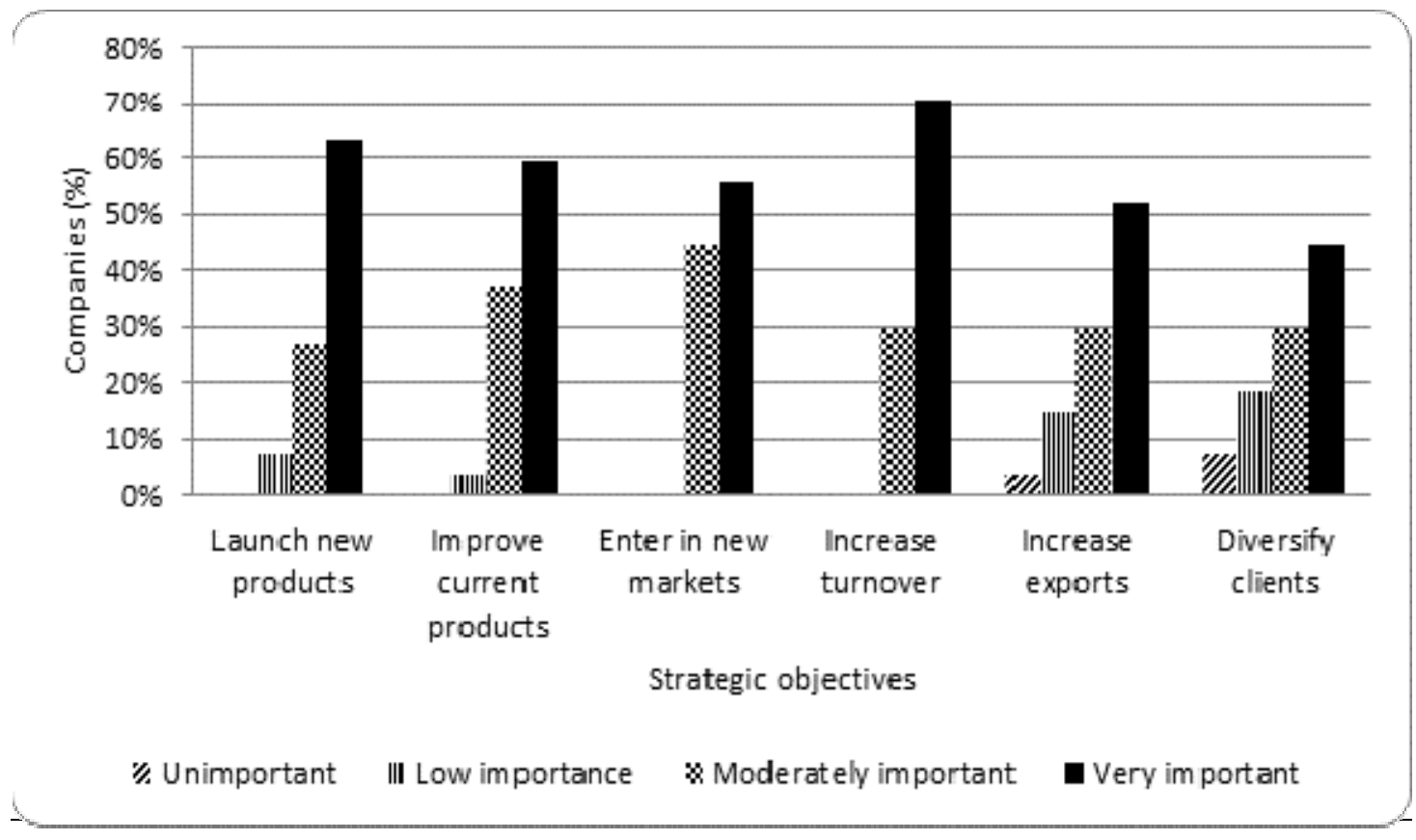

As to the markets, 16 firms (60\% of the total) export, while the remaining are focused on the domestic market only. However, exports play a modest role, if any, for most companies. In fact, only 5 respondents stated they exported more than $40 \%$ of total sales. The EU countries and the Portuguese-speaking countries are the main destinations.

Most of the companies provide (63\%) or acquire services (82\%) on an outsourcing basis. This is a structural aspect of the software industry, where specialization is a necessity for small and medium sized firms. This makes them establish a large number of commercial and technological/commercial partnerships as well as the multiplication of occasional transactions. This phenomenon underpins the development of networks, which are a permanent element of the 
organization of this industry. These networks comprise both technology-oriented linkages and market-oriented linkages (see Grimaldi and Torrisi, 2001).

Almost all companies, i.e., 25 out of 27, stated they carry out R\&D activities (Table 3). The average investment in these activities represents $15 \%$ of the total turnover. Around a quarter of the employees are engaged in R\&D activities. This represents a strong orientation towards innovation, which is understandable both in light of the type of customers and the strategy our companies tend to adopt, as already pointed out (Aramand, 2008; Tsang, 2005). When asked about their current technological strategy, the large majority of the firms mentioned applied research activities, alone or in combination with other forms of R\&D. Only two of 27 companies mentioned basic research alone or product improvement alone (Figure 5). Furthermore, four firms employ holders of PhDs, although they represent a modest share of total employees (Table 1).

Table 3 - R\&D activities and patents

\begin{tabular}{lc}
\hline Companies with R\&D activities & $\begin{array}{c}\text { Number and valid percentage of } \\
\text { companies }\end{array}$ \\
Without & $2(7.4)$ \\
With & $25(92.6)$ \\
Total & $27(100.0)$ \\
NA & 0 \\
Average percentage of R\&D & 12.9 \\
investment in the total turnover & \\
Average percentage of employees in & 25.1 \\
R\&D activities & \\
Companies with applied patents & $22(81.5)$ \\
Without & $5(11.5)$ \\
With & $27(100.0)$ \\
Total & 0 \\
NA & \\
\hline
\end{tabular}

However, only five companies have applied patents. This may be due to the type of firms we are dealing with in terms of products and size. In fact, patents are filed mostly by firms that produce software products rather than software services. 
FIGURE 5 - Technological strategy

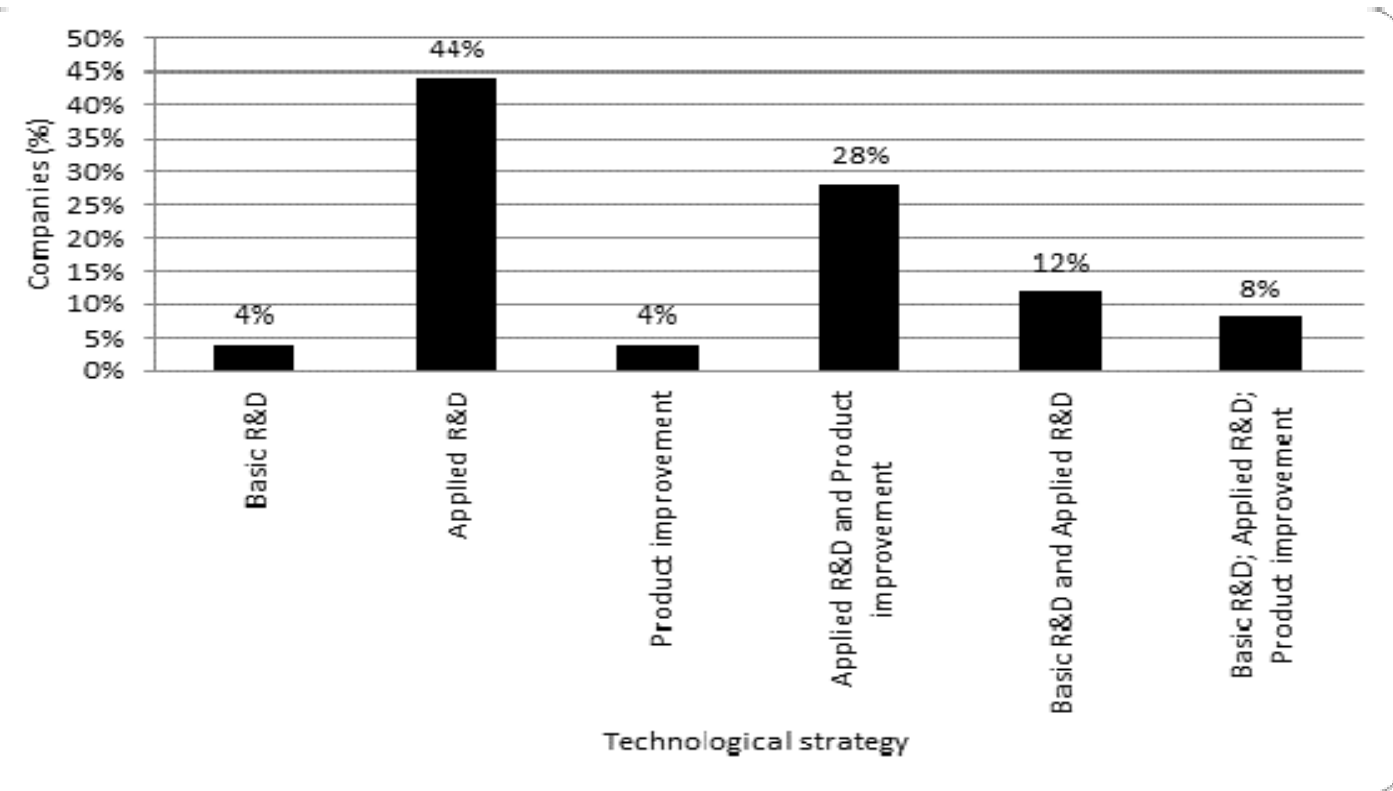

Turning to the main sources of funding, a great majority rely on equity financing (93\%), which represents $70 \%$ of total funding on average. Only 8 companies resorted to bank loans. Ten used some kind of public incentive which represented an average of just $4 \%$ of total funding. Venture capital is not very significant here as it was used by only 5 companies (Table 4). These figures may indicate two things: first, the initial capital to create a company is relatively low; and second, time to the market is relatively short.

Table 4 - Sources of funding

\begin{tabular}{lc}
\hline & $\begin{array}{c}\text { Number and valid percentage of } \\
\text { companies }\end{array}$ \\
\hline Equity & $23(92.0)$ \\
Loans & $7(28.0)$ \\
Venture capital & $5(20.0)$ \\
Public incentives & $9(36.0)$ \\
Total & 25 \\
NA & 2 \\
$\begin{array}{l}\text { Average percentage of equity in total } \\
\text { funding }\end{array}$ & 68.4 \\
Average percentage of loans in total \\
funding \\
Average percentage of venture capital \\
in total funding \\
$\begin{array}{l}\text { Average percentage of public } \\
\text { incentives in total funding }\end{array}$ \\
\hline
\end{tabular}




\section{THE ENTREPRENEURIAL EVENT}

\subsection{The entrepreneurs and the entrepreneurial event}

At the time of the entrepreneurial event (Feldman, 2001), or the formation of the company, the entrepreneurs were very young (Figure 6): While the average age was 31 years, more than half (52\%) were less than 30 and almost $80 \%$ were 35 or younger. At the time of the interview, the average age of the entrepreneurs had risen to 39 years whilst about $40 \%$ were still 35 years or younger and more than half (60\%) were 39 or less.

FIGURE 6 - Age of the entrepreneurs at start-up year

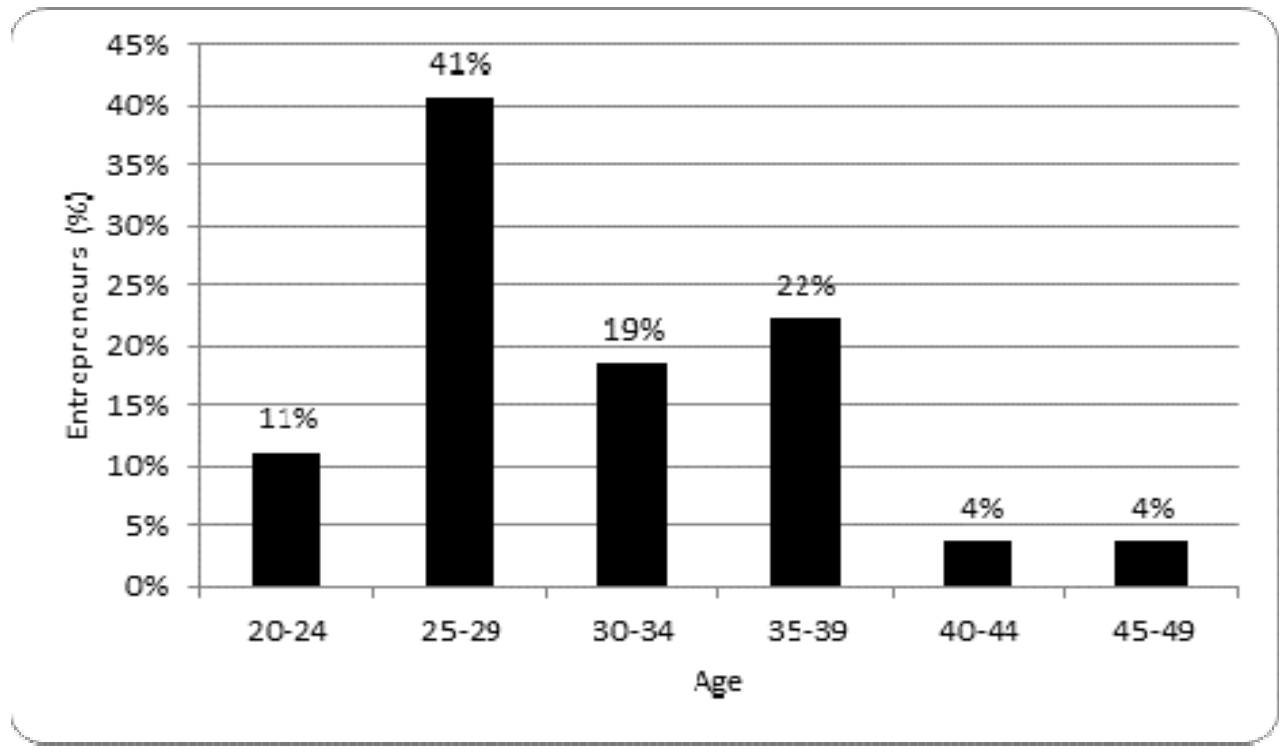

As for their educational background at that time, 37\% of the entrepreneurs held a bachelor's degree, $30 \%$ held a post graduate academic specialization, $15 \%$ held a master's degree, $11 \%$ had undergraduate education only and 7\% (two entrepreneurs) had obtained a PhD degree (Figure 7). 
FIGURE 7 - Education at start-up year

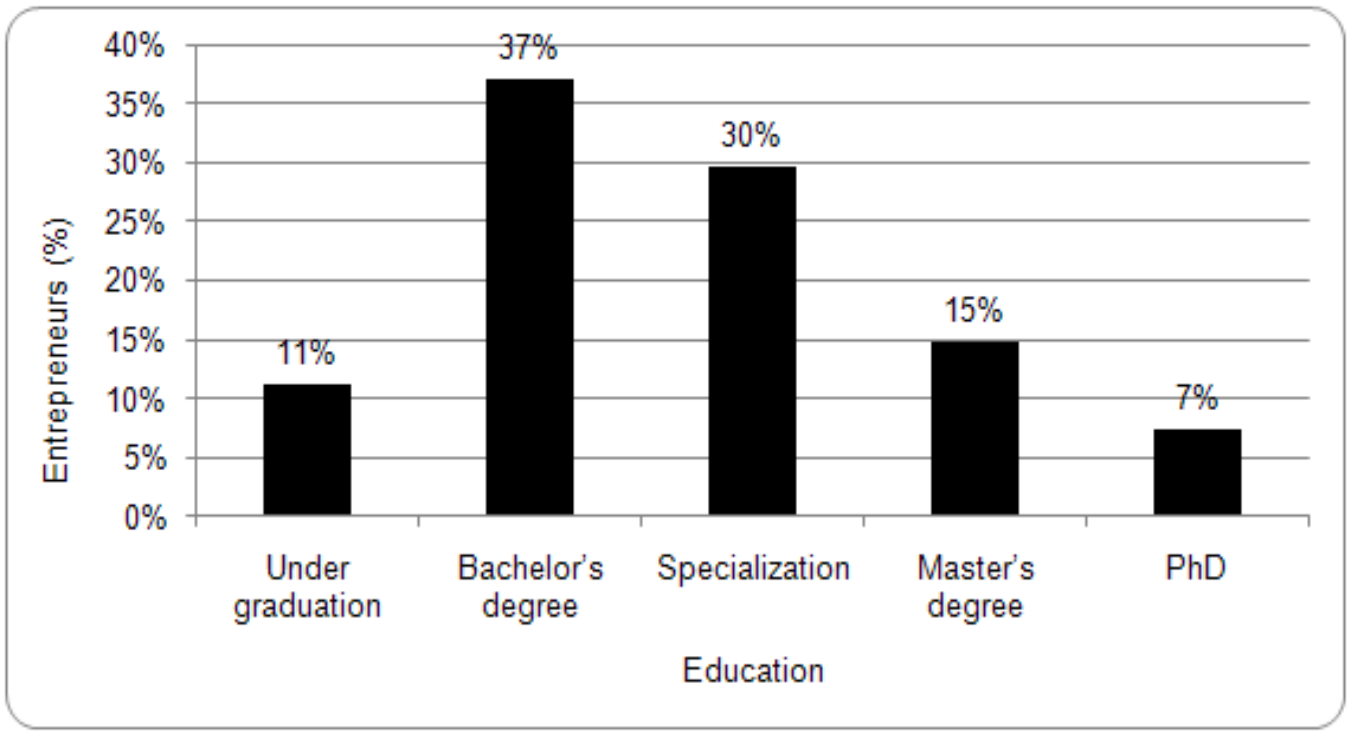

When observing their professional trajectories, we find that, despite their youth, the large majority already had some experience in the industry and had participated in entrepreneurial ventures before the entrepreneurial event or joining the company (Figure 8). Around 35\% of the entrepreneurs had technical experience in the software industry and $23 \%$ had some commercial experience. In terms of management or entrepreneurial experience, $19 \%$ had already formed at least one company and $77 \%$ of them had some kind of management experience prior to the entrepreneurial event. This is quite a relevant aspect because it may constitute one of the factors underlying the success of these firms. In fact, management experience is reported in the literature as a major aspect for success in software firms (Giarratana et al, 2004).

FIGURE 8 - Entrepreneurs’ previous experience in the start-up year

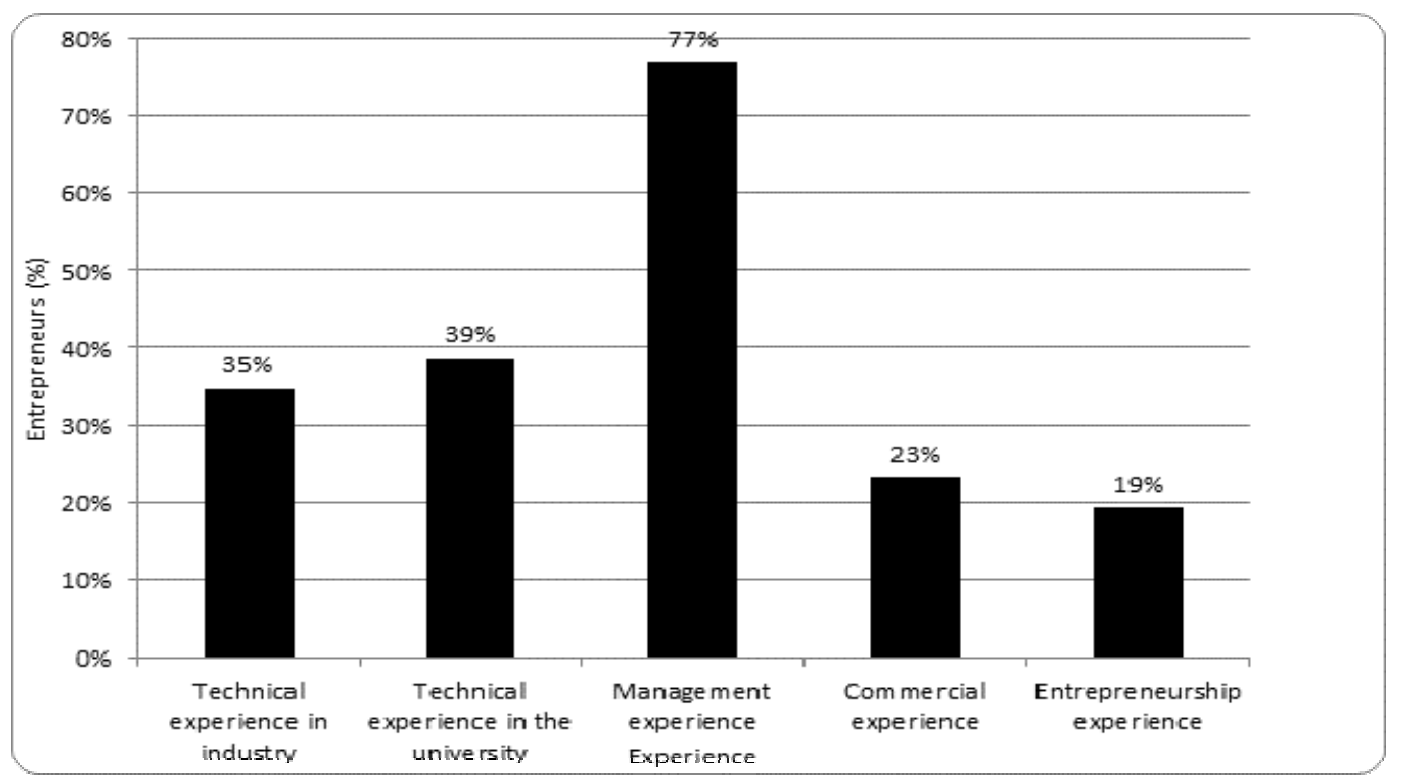

DINÂMIA'CET - IUL, Centro de Estudos sobre a Mudança Socioeconómica e o Território 
Regarding their position in the firm, around half are CEOs and $22 \%$ refer to themselves as founding partners only and $15 \%$ as general managers. Only $7 \%$ hold the position of chief commercial officer or chief financial officer. One of them is non-executive president.

Turning to their current academic background, most entrepreneurs have continued to invest in their academic education even though, and unlike other more science-based sectors (such as biotechnology) they are seldom pursuing academic careers. Indeed, most of the entrepreneurs (62\%) have never worked in academia, which is reflected by the fact that only $32 \%$ have published at least one scientific paper. On the other hand, the majority (60\%) stated they had participated in research projects or research teams.

As to the scientific area of the last degree completed, the majority of the entrepreneurs obtained a degree in engineering or management ( $41 \%$ in each area) and only $7 \%$ in computer sciences. If we also look at the scientific area of the first academic degree obtained, we find that the postgraduate degree of 12 (63\%) of the 19 entrepreneurs with postgraduate education was in a different scientific area from their initial academic training. This is mainly due to the fact that most entrepreneurs with degrees in engineering chose to do post-graduate studies in management: while $74 \%$ of the 19 entrepreneurs graduated in engineering, only $26 \%$ of them continued studies in this area and $58 \%$ opted for post-graduate degrees in management and related areas. This is a common trend in science or technology-based sectors where most entrepreneurs perhaps feel the need to get some management knowledge and expertise either by hiring professionals in this area or by actually studying for academic degrees such as MBAs. Moreover, most of the entrepreneurs (19 out of the 27) referred that they had enrolled in additional courses and training, $21 \%$ of which were on entrepreneurship.

The professional and/or academic trajectory led $67 \%$ of the entrepreneurs to a period abroad, especially in the United States (39\% of the entrepreneurs who stayed abroad went to the USA). The great majority of entrepreneurs who went abroad (78\%) created networks during this period that are still active and mobilized towards the firms' activities. We may conclude that the internationalization of the entrepreneurs is likely to have been important in the further development of the firms. 


\subsection{Characteristics of the entrepreneurial event}

When entrepreneurs were asked about their main motivations to start a business, the identification of a new business opportunity assumed great importance. Indeed, $48 \%$ of the entrepreneurs stated that the identification of an opportunity had been a major motivation to set up a firm and around $33 \%$ mentioned opportunity recognition as the only motivation.

The entrepreneurs' personality traits and personal expectations is the next motivation. Almost 26\% said that the desire for risk, innovation and challenges was one of the main drivers of the entrepreneurial event (with 19\% stating these factors were the exclusive drivers); on the other hand, almost 30\% said the main motivations for creating a new business included the desire to be financially and personally independent and in control of their destiny (for 15\% these are their prime motivations). About $11 \%$ were driven by the wish to exploit a new technology or apply research outputs.

As for the favourable conditions and supportive factors during the business start-up stage, the entrepreneurs mentioned the favourable business environment and economic situation (33\%), government support (national and local) (22\%), the existence of a main customer from the outset, (19\%) and the exploitation of a previously mobilized network (15\%), as well as some other less important factors.

Regarding the main obstacles and unfavourable conditions, the entrepreneurs mentioned domestic market limitations or related problems and challenges (26\%), the economic downturn (19\%), bureaucracy surrounding company start-up and early development (15\%), difficulties in finding and recruiting highly skilled human resources (11\%), other personal factors like stress or lack of knowledge (11\%) as well as some other less important factors. Conversely, almost $19 \%$ of the entrepreneurs stated that they faced no specific kind of obstacle or unfavourable condition. 


\section{SOCIAL NETWORKS AND THE ENTREPRENEURIAL EVENT}

In this section we address the issue of the role of the entrepreneurs' informal networks in accessing resources in the early stages of the firms' life, i.e. the formation year and the two subsequent calendar years. We begin by inquiring how the entrepreneurs in this sector perceive the importance of these informal networks to both the firm's and their personal performance. We then analyse the role of these networks in accessing three types of resource: opportunity and access (O\&A); knowledge; and power and influence (P\&I) (Castilla, 2000). To do so, we start by describing and interpreting the general composition and structure of the aggregate networks that include all of these resources and then compare knowledge networks with those used to access the other two types of resource.

\subsection{The importance of networks in the start-up stage}

One of the main ideas in the literature about entrepreneurship and networks is that the entrepreneur obtains a significant part of both the tangible and intangible resources necessary for the company's success through his social network (Greve \& Salaff, 2003; Singh, 2000). Thus, we can only fully understand the entrepreneurial process by addressing the social networks built and mobilized by the entrepreneurs to achieve their goals (Johannisson, 1998; Murray, 2004).

The entrepreneur can establish contact with his personal entourage, such as family and close friends, former university colleagues, former co-workers and acquaintances. This personal network (informal) is particularly important in the early stage (the first three years) of the company (Bruderl \& Preisendorfer, 1998; Elfring and Hulsink, 2003; Ozman, 2009); this period is characterized by the lack of capital and human resources as well as by a high level of uncertainty.

Family and friends may provide the necessary emotional support and initial funding to motivate the entrepreneur to pursue and achieve innovation and drive the company to a mature stage.

We can observe from the sample that half of the entrepreneurs perceived the support of their friends/acquaintances/family networks in the start-up process as extremely or very important, while only $8 \%$ perceived these networks to be of no importance. Additionally, entrepreneurs also understood these networks to be extremely or very important for both their own performance during the firms' early development (around 38\%) and the firms' performance at that stage (42\%). In addition to confirming the role of these ties both for the entrepreneur and for the firm, the findings also highlight the awareness of this importance among the entrepreneurs themselves. 


\subsection{The role of networks to access resources}

The literature agrees on the fact that a plethora of resources is required for the entrepreneurial process. In the case of technological entrepreneurship, the resources sought by the entrepreneurs through their social networks include scientific and technological knowledge (crucial in this knowledge-intensive sector), management knowledge, decision-making support, information on market opportunities and access to funding, as well as qualified human resources (Mangematin et al, 2002; Chesbrough and Rosenbloom, 2002; Mustar et al, 2006; Castilla et al., 2000; Granovetter, 1973; Saxenian, 1994).

One of the most immediate conclusions that we can draw on the importance of the entrepreneurs' informal networks in obtaining these resources is that a very significant number of these entrepreneurs used their informal networks at least once a month to obtain technological (67\%) and scientific (31\%) knowledge and access highly skilled human resources (37\%). In terms of more business-oriented resources, the entrepreneurs also tried to obtain information on a monthly or more frequent basis about the domestic market and clients (70\%), external markets and foreign clients (41\%), prospective partnerships (44\%) and access to critical complementary assets, such as skills and competencies in marketing and production (33\%). These networks were not used so often to access information about capital and subsidies and external funding, which can mean either that informal networks might be less adequate for this purpose or that the necessary contacts are not so frequent.

These informal networks are also of overriding importance in the hiring of skilled personnel, an issue that entrepreneurs generally refer to as somewhat problematic. For recruitment in the start-up stage, $44 \%$ of the entrepreneurs resorted to friends' advice to find and recruit workers, $41 \%$ relied on former coworkers' advice and 33\% turned to former classmates, the same percentage as those who relied on job advertisements. In this stage, on average about $65 \%$ of new employees were recruited using advice from former co-workers, friends, classmates and former employees and only 19\% through job advertisements and 17\% through other diligences. These findings corroborate the importance of the informal relations entrepreneurs build over their academic, professional and personal life when accessing crucial resources for the firm.

To answer our research question on the role the entrepreneurs' informal networks played in accessing resources in the early stages of the firms' life, entrepreneurs were invited to: a) identify the individuals, as well as their institutional affiliation, they usually asked for inputs and advice about three different types of resource/knowledge - scientific and technological knowledge; 
management; and decision-making (concerning the most crucial and strategic decisions for the company); and b) state the frequency of the contacts with these individuals (on a 5 point scale from daily to yearly).

The subsequent analysis starts by focusing on a statistical description of these networks, addressing first the aggregate networks and then separating the knowledge network from the network mobilized to access the other resources. This analysis takes into account: the size of the networks; their composition (by type of actor involved, in percentage); the diversity of actors within the networks (number of different types of actors involved); and the strength of the ties (proxied by the frequency of contacts).

\subsubsection{The aggregate ego-networks for all kinds of resource}

In the start-up period, 96 significant relations to obtain the three types of resource under analysis are mobilized by the entrepreneurs through the aggregate informal networks: Knowledge; Opportunity \& Access; and Power \& Influence (see Table 5).

Although firms from other sectors are the most frequent institutions in these networks (38\%), there is also a relevant presence of universities and research centres (21\%). Mobile communications operators and multinational corporations operating in the software industry represent $25 \%$ of the actors and are usual partners in some of the most significant R\&D activities. Portugal Telecom and mobile operators such as TMN, Optimus and Vodafone are the most represented operators in the networks, while in the case of multinationals, Microsoft, Ericsson and Hewlett-Packard also appear in several firms' networks. Firms from the same sector (6\%), financial institutions (5\%) and other institutions (5\%) are the least represented. As to the variety of alter actors in the firms' networks, the average number of different types is 2.2 .

As expected from (Salavisa et al, 2009; Hite and Hesterly, 2001), entrepreneurs tend to have a small number of informal links in the initial stage (3.5 in average) and these are very strong (an average strength of 1.9 on a scale from 1 to 2 , where 1 denotes a weak tie and 2 represents a strong tie; moreover, $83 \%$ of the relationships are strong, i.e. have a high frequency).

It should also be stressed that 10 entrepreneurs established strong relationships with universities to obtain various resources in the start-up period, notably scientific and technological knowledge to their firms. Concerning the localization of the alter institutions, 13 firms (out of 27) have at least 
one relationship with an international institution; international links represent $21 \%$ of the total links established by these firms.

5.2.2 A comparison of the ego-networks of Knowledge versus the aggregate networks of Opportunity \& Access and Power \& Influence

We now present an interpretative comparison of the knowledge networks versus the two other networks combined i.e. O\&A and P\&I (see Table 5). Since we are dealing with a knowledgeintensive sector, it is not surprising that the relationships established to obtain knowledge predominate: 67 vis-à-vis 44 for all other resources combined.

Table 5 - Composition and structure of the networks in the software sector

\begin{tabular}{lccc}
\hline Measures & $\begin{array}{c}\text { Aggregate } \\
\text { networks }\end{array}$ & $\begin{array}{c}\text { Knowledge } \\
\text { networks }\end{array}$ & $\begin{array}{c}\text { Networks to } \\
\text { access other } \\
\text { resources }\end{array}$ \\
\hline Total number of actors ${ }^{\text {a }}$ & 96 & 67 & 44 \\
Average number of actors & 3.55 & 2.48 & 1.63 \\
\% firms from the sector & $6 \%$ & $13 \%$ & $7 \%$ \\
\% multinationals and operators & $25 \%$ & $22 \%$ & $20 \%$ \\
\% universities and R\&D centres & $21 \%$ & $27 \%$ & $14 \%$ \\
\% firms from other sectors & $38 \%$ & $25 \%$ & $52 \%$ \\
\% financial institutions & $5 \%$ & $4 \%$ & $7 \%$ \\
\% S\&T parks & $0 \%$ & $0 \%$ & $0 \%$ \\
\% other institutions & $5 \%$ & $7 \%$ & $0 \%$ \\
\% international ties & $21 \%$ & $26 \%$ & $12 \%$ \\
\% of strong ties & $83 \%$ & $79 \%$ & $70 \%$ \\
Average strength of ties & 1.86 & 1.7 & 1.6 \\
Average variety of actors & 2.2 & 2 & 1.2 \\
\hline
\end{tabular}

\section{Notes:}

${ }^{\text {a }}$ The same actor can be present in both types of network.

${ }^{\mathrm{b}}$ Due to the existence of multiplex ties some institutions might be present in more than one type of network simultaneously even though that institution is counted only once in the aggregated network. This accounts for the apparent discrepancy in total and partial values between the aggregated network and the other networks.

Striking differences appear regarding the composition of the networks. According to our classification, universities and research centres are predominant in knowledge networks, closely followed by firms from other sectors and by mobile communications operators and multinational corporations operating in the software sector. Firms from the same sector are less relevant, as are other institutions and financial institutions, which have a small share. Naturally, if all different types of firm were combined they would clearly be the most predominant type of institutions even in these knowledge networks. The average strength of the ties is very high and most of the relationships are very frequent. Nine entrepreneurs established strong personal relationships with 
universities and research centres to obtain knowledge and 12 developed international relationships for the same purpose. International ties represent $26 \%$ of the total ties.

Taking O\&A and P\&I networks together, we find that they differ from the above on several grounds. Firms from other sectors are very predominant in the composition; mobile communications operators and multinational corporations operating in the software sector follow but at a great distance. The role of universities to obtain these resources is clearly inferior (14\% and only 4 entrepreneurs with strong ties to universities), as is that of firms from the same sector. Meanwhile, financial institutions have a more important share than in knowledge networks.

Although on average the ties remain strong, they are less so indicating that the access to management knowledge and decision making resources implies less frequent relationships than the access to knowledge resources. The former relationships are considerably less internationalized (only 5 entrepreneurs had international relationships in the initial stage and the international ties represented $12 \%$ of the total ties).

\section{THE CONTRIBUTION OF SOCIAL NETWORKS TO INNOVATIVE ACHIEVEMENTS}

\subsection{Entrepreneurs' profile, network configuration and innovative performance: main propositions}

The question addressed now is: in what way, if any, are start-up stage networks associated with the innovative performance of the software for telecommunications firms? We have already pointed out that entrepreneurs assign a high value to their personal networks in the early stage of their business. We have also described and interpreted the composition and structure of these initial networks in the software for telecommunications sector. We now look for the existence of an association between that composition and the further innovative pattern of the firms. We also take into account the entrepreneurs' background and the specific origin of their companies, i.e., whether they are academic spin-offs.

To deal with this issue, we have split the sample into two groups, according to the main type of product of the companies: the more radically innovative firms with characteristics similar to those of science-based industries; and application-oriented firms which mainly carry out incremental innovation through technological improvements. 
For analytical purposes, we have formulated a set of propositions on the relationships between aprioristic relevant characteristics of the entrepreneurs, their personal networks, and the firms' origin on the innovative pattern of the firms.

Firstly, the entrepreneurs' specific background can be expected to impact the composition of the initial networks. Thus, a demanding academic training with some international component is likely to be reflected in a large number of relationships with the two main sources of technological knowledge in the sector, i.e. universities and multinationals. In accordance with this conjecture, we propose:

Proposition 1 - Entrepreneurs with an international academic background develop proportionally more relationships with universities.

Proposition 2 - Entrepreneurs with an international academic background develop proportionally more relationships with multinationals.

The question now is whether there is a direct connection between the composition of the entrepreneurs' initial personal networks and the firms' patterns of innovativeness. Due to the role of universities as scientific and technological knowledge providers and of IT multinationals as a source of technological and advanced management knowledge, their presence in the entrepreneurs' networks is a potential positive factor for the success of strategies aimed at innovation. Consequently, we propose that:

Proposition 3 -The higher the proportion of universities in the start-up networks, the more likely it is the firms will adopt a radical innovation strategy.

Proposition 4 - The higher the proportion of multinationals in their start-up networks, the more likely it is the firms will adopt a radical innovation strategy.

The next proposition stems strictly from logical transitivity between propositions 1 and 3 . The entrepreneurs' background can be expected to be directly connected with the innovative pattern of their firms. In fact, an international academic background might favour the success of a more radical innovation strategy. This is due to the fact that it is likely that the entrepreneurs with this kind of training will have been exposed to more advanced scientific and technological contexts more challenging and diversified life experiences. We therefore propose that: 
Proposition 5 - Entrepreneurs with an international academic background tend to set up firms that adopt a strategy of radical innovator.

Regarding the firm's origin, a connection can be expected between an academic spin-off and a higher propensity to be a radical innovator. Therefore we propose that:

Proposition 6 - Academic spin-offs are more frequently radical innovators than firms with a different origin.

\subsection{Testing the propositions}

To conduct the empirical work, recently formed firms (2006 onwards) had to be dropped in order to have a sufficient gap to analyse the impact of initial networks on the current performance. Thus, we retained 23 firms that were classified according to their innovative profile, based on the analysis of the qualitative information about the companies' products and services obtained through the interviews and documental data: the more radical innovative firms with characteristics similar to those of science-based industries; and the application-oriented ones, which carry out mostly incremental innovation through technological improvements. Firms were considered to pursue a radical innovation strategy if they develop software that is new to the market. Twelve companies fall into this group, developing new mobile platforms for applications in advanced geo-localization, payment systems, fusion between mobile phones and internet and games. Firms were considered to pursue an incremental strategy if they develop services that are not new to the market. Eleven companies fall into this group, and their main focus is software customization or product improvement.

To test the propositions 1 to 4 presented above, the Mann-Whitney test was performed. This test enables to determine the existence of statistically significant differences between two groups of firms (two independent samples²). Results are reported in Table 6. In all cases involving the composition of the networks, we performed the test using the aggregate networks on one hand, and the knowledge networks on the other hand. In fact, the latter are central in knowledge-intensive sectors as they provide continuous access to scientific and technological knowledge in the innovation process.

An international academic background appears as positively associated with the share of universities in the total number of actors of the aggregate networks. Thus, propositions 1 holds but only for aggregate networks. Results do not support proposition 2, as we find no significant

\footnotetext{
${ }^{2}$ The option for this test stems from the fact that the variables do not follow a normal distribution, according to Kolmogorov-Smirnov and Shapiro-Wilk tests of normality.
} 
differences in the share of multinationals in the firms' networks associated with the existence of an international academic background of the entrepreneurs.

Table 6 - Differences between the groups of firms

\begin{tabular}{|c|c|c|c|c|}
\hline Proposition & Variable & Groups & Statistics & Value \\
\hline 1 & $\begin{array}{l}\text { Share of universities } \\
\text { in aggregate network }\end{array}$ & $\begin{array}{c}\text { With international background } \\
\text { Without international background }\end{array}$ & $\begin{array}{c}\text { Mean Rank } \\
\text { Mean Rank } \\
\text { Mann-Whitney U }\end{array}$ & $\begin{array}{r}14.60 \\
10.00 \\
39.0^{a}\end{array}$ \\
\hline 1 & $\begin{array}{l}\text { Share of universities } \\
\text { in knowledge network }\end{array}$ & $\begin{array}{l}\text { With international background } \\
\text { Without international background }\end{array}$ & $\begin{array}{c}\text { Mean Rank } \\
\text { Mean Rank } \\
\text { Mann-Whitney } U\end{array}$ & $\begin{array}{r}13.10 \\
11.15 \\
54.0\end{array}$ \\
\hline 2 & $\begin{array}{c}\text { Share of } \\
\text { multinationals in } \\
\text { aggregate network }\end{array}$ & $\begin{array}{c}\text { With international background } \\
\text { Without international background }\end{array}$ & $\begin{array}{c}\text { Mean Rank } \\
\text { Mean Rank } \\
\text { Mann-Whitney } U\end{array}$ & $\begin{array}{r}12.30 \\
11.77 \\
62.00\end{array}$ \\
\hline 2 & $\begin{array}{c}\text { Share of } \\
\text { multinationals in } \\
\text { knowledge network }\end{array}$ & $\begin{array}{c}\text { With international background } \\
\text { Without international background }\end{array}$ & $\begin{array}{c}\text { Mean Rank } \\
\text { Mean Rank } \\
\text { Mann-Whitney U }\end{array}$ & $\begin{array}{r}13.60 \\
10.77 \\
49.00 \\
\end{array}$ \\
\hline 3 & $\begin{array}{l}\text { Share of universities } \\
\text { in aggregate network }\end{array}$ & $\begin{array}{c}\text { Radical innovators } \\
\text { Incremental innovators }\end{array}$ & $\begin{array}{c}\text { Mean Rank } \\
\text { Mean Rank } \\
\text { Mann-Whitney }\end{array}$ & $\begin{array}{l}15.08 \\
8.64 \\
\mathbf{2 9 . 0 0 ^ { b }}\end{array}$ \\
\hline 3 & $\begin{array}{l}\text { Share of universities } \\
\text { in knowledge network }\end{array}$ & $\begin{array}{c}\text { Radical innovators } \\
\text { Incremental innovators }\end{array}$ & $\begin{array}{c}\text { Mean Rank } \\
\text { Mean Rank } \\
\text { Mann-Whitney }\end{array}$ & $\begin{array}{l}15.25 \\
8.45 \\
27.00^{b}\end{array}$ \\
\hline 4 & $\begin{array}{c}\text { Share of } \\
\text { multinationals in } \\
\text { aggregate network }\end{array}$ & $\begin{array}{c}\text { Radical innovators } \\
\text { Incremental innovators }\end{array}$ & $\begin{array}{c}\text { Mean Rank } \\
\text { Mean Rank } \\
\text { Mann-Whitney } \\
\end{array}$ & $\begin{array}{r}11.38 \\
12.68 \\
58.50 \\
\end{array}$ \\
\hline 4 & $\begin{array}{c}\text { Share of } \\
\text { multinationals in } \\
\text { knowledge network }\end{array}$ & $\begin{array}{l}\text { Radical innovators } \\
\text { Incremental innovators }\end{array}$ & $\begin{array}{c}\text { Mean Rank } \\
\text { Mean Rank } \\
\text { Mann-Whitney }\end{array}$ & $\begin{array}{l}12.13 \\
11.86 \\
64.50\end{array}$ \\
\hline
\end{tabular}

Notes: $\mathrm{N}=23$; $^{\mathrm{a}}$ significant at 0.10 level; ${ }^{\mathrm{b}}$ significant at 0.05 level; ${ }^{\mathrm{c}}$ significant at 0.01 level.

Concerning propositions 3 and 4 that relate the composition of initial networks with the firms' innovative behaviour, significant effects only emerge in the case of the share of universities: firms which have become more radical innovators had a higher proportion of universities in initial - both aggregate and knowledge - networks. This result confirms what is generally intuitive, but it is interesting here because we are dealing with a sector that is usually described as not very dependent on universities (Malerba and Torrisi, 1996; Weterings and Boschma, 2009). In our case, however, links with universities seem to have been extensively used by the entrepreneurs that were able to create the more radically innovative firms in the sector. This brings support to proposition 3. Conversely, the share of multinationals in both networks means there is not a significant difference between the two groups of firms, so proposition 4 does not hold.

The next step consists of trying to establish a direct connection between the two ends of a chain of causal relationships, i.e., from the entrepreneur's academic background straight to the innovative pattern where the composition of the networks is the intermediate link. Unfortunately, there is no such direct connection, as we can conclude from the Fisher's exact test reported in Table 7. As such, proposition 5 does not hold. A relation between the entrepreneur's academic training and his 
firm's innovative behaviour exists but only when mediated by the type of network he/she built in the start-up stage.

Table 7 - International academic background and innovation behaviour: cross tabulation

\begin{tabular}{|c|l|c|c|c|}
\cline { 2 - 4 } \multicolumn{2}{c|}{} & \multicolumn{2}{c|}{ International academic background } & \multirow{2}{*}{ Total } \\
\cline { 2 - 5 } \multicolumn{2}{c|}{} & No & Yes & \\
\hline \multirow{2}{*}{$\begin{array}{c}\text { Radical } \\
\text { innovator }\end{array}$} & No & 8 & 3 & 11 \\
\cline { 2 - 5 } & Yes & 5 & 7 & 12 \\
\hline \multicolumn{2}{|c|}{ Total } & 13 & 10 & 23 \\
\hline
\end{tabular}

Fisher's exact test exact significance $(2$-sided $)=0.214$; Phi $=0.313($ sig. $=0.133)$

A mere look of the data reveals that 6 of the 12 more radically innovative firms were originally academic spin-offs, as opposed to 2 of the 11 more application-oriented firms. Or, to put it another way, out of a total of 8 academic spin-offs, 6 have become radical innovators. Conversely, almost all corporate spin-offs became application-oriented companies (4 of 5). A preliminary observation therefore seems to corroborate the existence of a connection between the origin of the firm and the way its later development took place. However, the results of the tests reveal that the relation between the variables is not statistically significant (Table 8). The conclusion is that an academic origin is not a relevant reason for a firm to become a radical innovator (proposition 6 is not supported by the data).

Table 8 - Academic spin-offs and innovation behaviour: cross tabulation

\begin{tabular}{|c|l|c|c|c|}
\cline { 3 - 5 } \multicolumn{2}{c|}{} & \multicolumn{2}{c|}{ Academic spin-off } & \multirow{2}{*}{ Total } \\
\cline { 3 - 5 } \multicolumn{2}{c|}{} & No & Yes & 11 \\
\hline \multirow{2}{*}{$\begin{array}{c}\text { Radical } \\
\text { innovator }\end{array}$} & No & 9 & 6 & 12 \\
\cline { 2 - 5 } & Yes & 6 & 8 & 23 \\
\hline \multicolumn{2}{|c|}{ Total } & 15 & 6 & 11 \\
\hline
\end{tabular}

Fisher's exact test exact significance $(2$-sided $)=0.193$; Phi $=0.334($ sig. $=0.110)$

It is worth dwelling a little longer on the composition of the networks, which differ between the two groups of firms on several grounds. Taking the aggregate networks of all resources (knowledge; opportunity \& access; and power \& influence), we find several interesting contrasts. First, and on average, more radical innovators have more links than incremental ones. Second, universities are much more represented in radical innovators' networks (34\% of the total actors) than in application-oriented firms' networks (8\% only) (Figure 9). Third, most of the links with 
universities for radical innovators are strong, while the opposite applies to application-oriented firms.

A sharper contrast appears when we examine knowledge networks alone (Figure 10). First, radically innovative firms by far outnumber application-oriented firms in the average number of links. Second, there is a huge difference between the two types of firm in the share of universities in the total number of actors in the networks: $49 \%$ in the radical innovators' ego-networks vis-à-vis a mere $6 \%$ in the networks of the application-oriented firms. And the figures are $68 \%$ and $22 \%$ respectively for the radical innovators' networks and the other firms' networks if we consider the share of universities and multinationals together in the total number of networks' actors. Third, radical innovators have more strong links with universities than application-oriented firms. Fourth, strong links weigh much more in the knowledge networks of radical innovators than in those of the other firms (84\% against 65\%), while this does not occur in the aggregate networks (81\% and $82 \%$ respectively). Finally, there is a stronger presence of international entities in the knowledge networks (than in aggregate networks) of the two groups of firm, exceeding $20 \%$ of the total actors. However, application-oriented firms' networks have a higher proportion of international entities than radical innovators.

FIGURE 9 - The composition of the aggregate networks of the two groups of firms

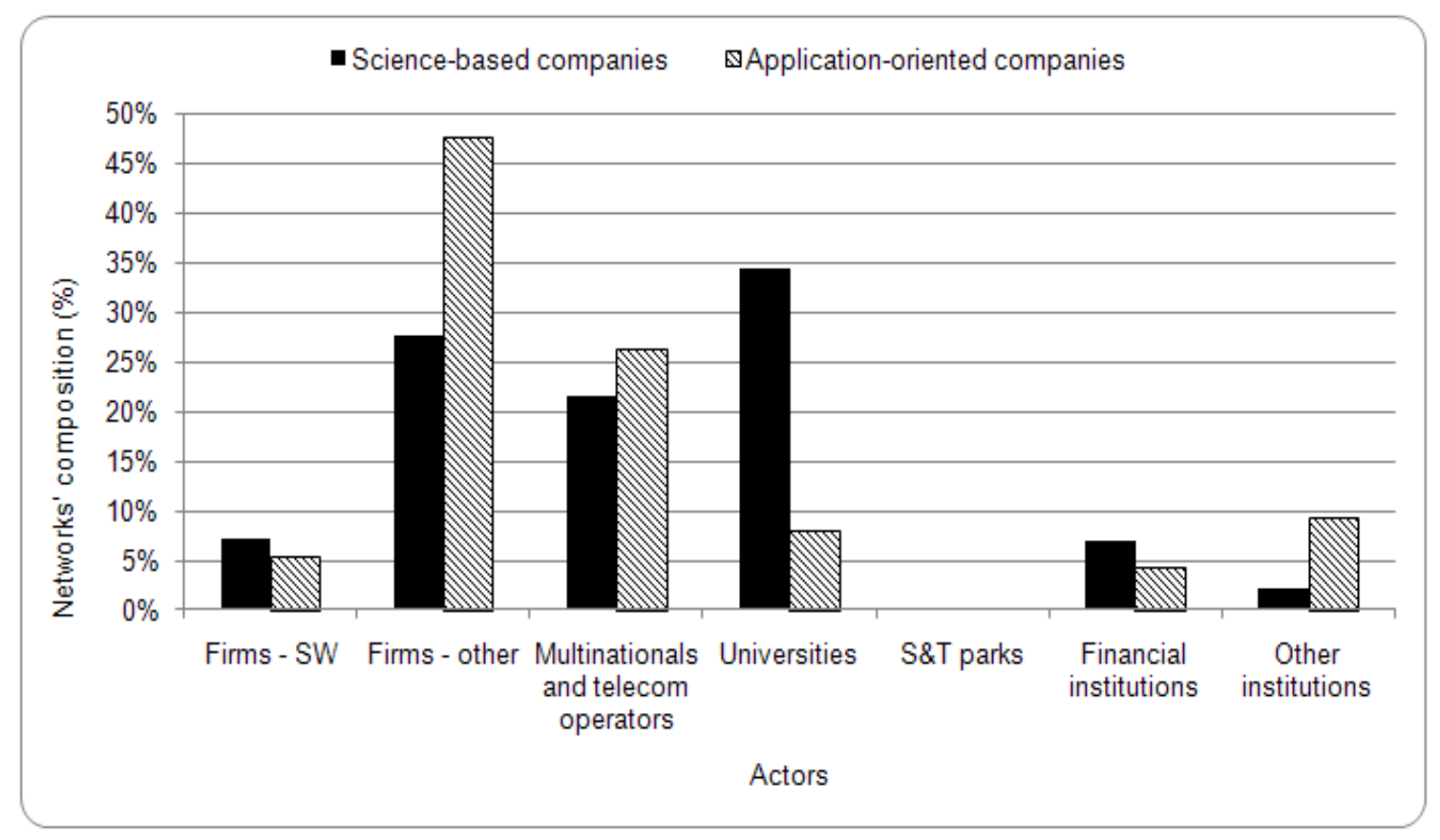


FIGURE 10 - The composition of the knowledge networks of the two groups of firms

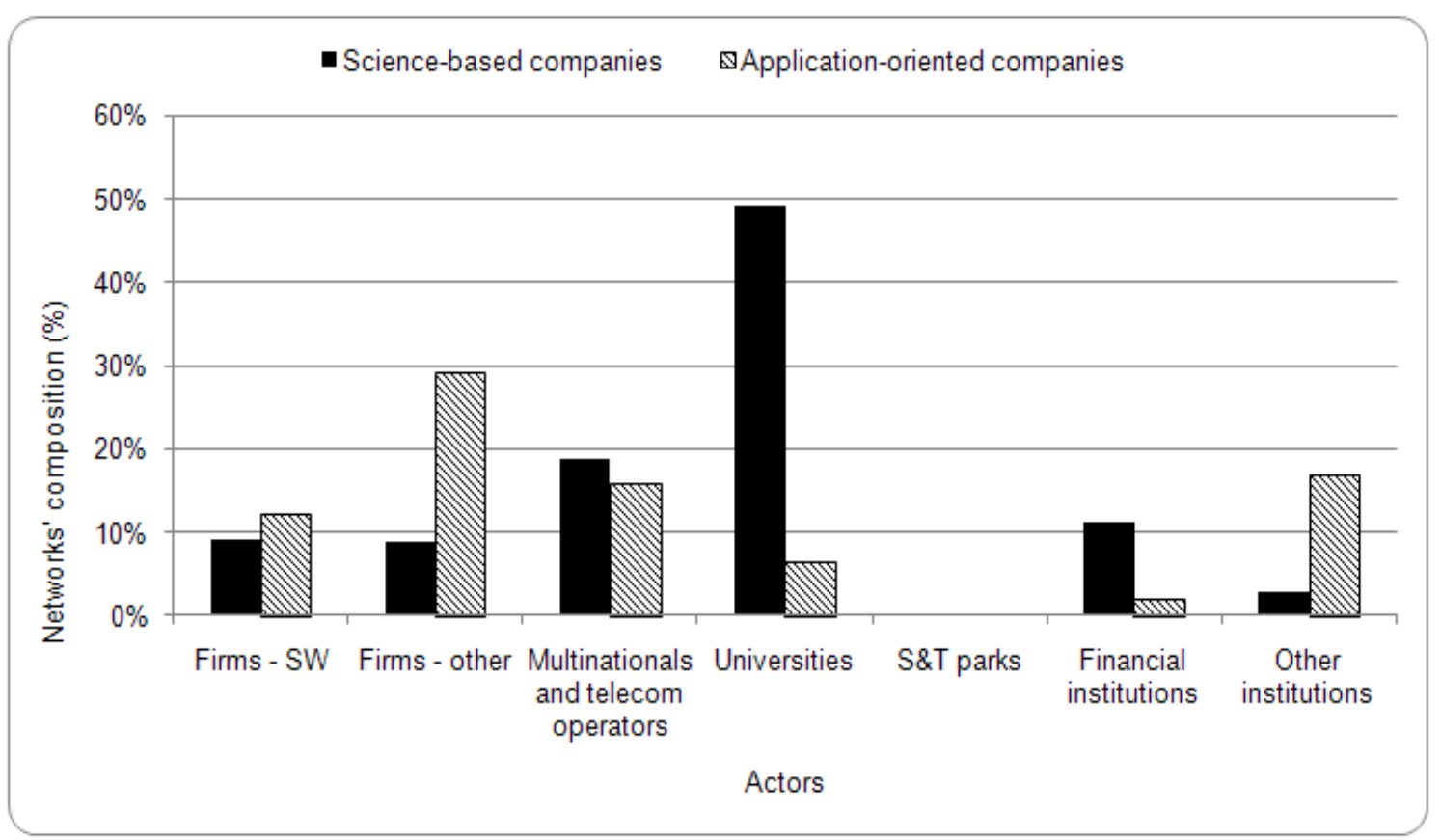

Some preliminary conclusions can be drawn at this point on the firms of the software for telecommunications sector in Portugal. First, we may claim that network composition is associated with the further innovative pattern of the companies. Secondly, the establishment of multiple ties with universities in the initial stage is more often adopted by radically innovative firms. Thirdly, the entrepreneur's academic background is connected with the configuration of networks built. Finally, there is no direct relationship between the entrepreneur's academic background and the innovative behaviour of the firm, but only an indirect connection mediated by the networks composition. To sum up, the configuration of the networks proves to be a major variable in explaining the firms' innovative behaviour, especially with regard the share of universities in the networks. 


\subsection{In search of an overall explanation of innovation in the software for telecommunications} sector

In the previous section we tested the relationships between some characteristics of the entrepreneurs, the composition of their networks in the start-up stage and the origin of the firms on the one hand, and the current profile of the companies regarding innovation on the other.

We now attempt to test a logistic model to ascertain which of the variables help explain a firm's propensity to become a radical innovator rather than an incremental innovator. We used a logistic model which includes four explanatory variables related to the network composition and the characteristics of the firms, since the entrepreneurs' background has proved to be of little help to explaining the innovative patterns. The variables are: share of the universities in the networks; share of the multinationals in the networks; age of the firm (log); and being an academic spin-off (binary). The two latter variables are control variables that are generally used in the literature on knowledge-intensive sectors (Mustar et al, 2006). The results are presented in Table 8.

According to the results of the tests, the model proves to be appropriate. We find that the large majority of the firms are correctly classified in the respective group (radical innovators versus application-oriented ones), notably when we use variables from the knowledge networks. In the latter case, the percentage of correctly classified firms reaches $83 \%$ of the total.

However, the only significant explanatory variable is the share of universities in the networks. This is an interesting result, consistent with the previous tests. It means that the role of universities in the entrepreneurs' networks is quite relevant to the innovative performance of the firms in this sector. This result - which is consistent with those of the previous section - may seem controversial when confronted with other empirical studies referred to above. But this is to a large extent only apparent. In fact, the large majority of the studies carried out elsewhere focus on the overall software industry, while here we are dealing with one of its most technologically advanced sectors. A second explanation might be the fact that our firms are mostly small and medium sized firms without sufficient endogenous capability in technological terms. This circumstance might make them look for external knowledge resources in universities. 
Table 8 - Estimation results

\begin{tabular}{|c|c|c|c|}
\hline Included variables & Statistic & Aggregate networks & Knowledge networks \\
\hline \multirow[t]{3}{*}{ Spin-off } & B & -2.280 & -1.643 \\
\hline & Wald & 1.966 & 0.953 \\
\hline & Odds ratio & 0.102 & 0.193 \\
\hline \multirow[t]{3}{*}{ Firm age (log) } & B & -6.737 & -6.681 \\
\hline & Wald & 2.247 & 1.870 \\
\hline & Odds ratio & 0.001 & 0.001 \\
\hline \multirow[t]{3}{*}{ Share of universities } & B & 7.356 & 6.739 \\
\hline & Wald & $4.743^{*}$ & $4.396 *$ \\
\hline & Odds ratio & 1565.362 & 845.090 \\
\hline \multirow[t]{3}{*}{ Share of multinationals } & B & 2.671 & 2.418 \\
\hline & Wald & 1.793 & 1.770 \\
\hline & Odds ratio & 14.461 & 11.228 \\
\hline \multirow[t]{8}{*}{ Constant } & B & 5.559 & 5.242 \\
\hline & Wald & 1.484 & 1.149 \\
\hline & Odds ratio & 259.662 & 189.018 \\
\hline & Cox \& Snell $\mathrm{R}^{2}$ & 0.420 & 0.463 \\
\hline & Nagelkerke $\mathrm{R}^{2}$ & 0.560 & 0.617 \\
\hline & Hosmer and Leshow test & 5.204 & 8.315 \\
\hline & & $(0.736)$ & $(0.403)$ \\
\hline & Overall percentage correct & 73.9 & 82.6 \\
\hline
\end{tabular}

Notes: * Significant at 0.05 level. 


\section{CONCLUSIONS}

This paper examines the factors affecting the innovative behaviour of firms in the Portuguese sector of software for telecommunications. This sector is composed of two distinct groups of firms: one more oriented towards radical innovation and the other more application-oriented in accordance with their products and services. Our main aim was to identify the key factors associated to each group and which may help understand the distinct trajectories of the firms in innovative terms. The entrepreneurs' (informal) networks have emerged as very relevant in explaining the different patterns of innovative behaviour of their companies.

Among the informal networks, we have focused on knowledge networks and aggregate networks. The former were built by the entrepreneurs to access scientific and technological knowledge and innovation opportunities. The latter consist of the aggregation of the former with the two other types of network: opportunity \& access, for access to knowledge and information about management, opportunities identification and tangible resources; and power \& influence to help decision-making on the companies’ most crucial and strategic decisions.

Our analysis has uncovered the relevance of the composition of the networks in terms of the diversity of actors, with great emphasis on the role of universities in the innovative process of the firms. More specifically, it was found that developing links with multiple universities in the early stage of the firms is associated with their later becoming a radical innovator rather than an application-oriented firm. Contrary to our expectations, the role of multinational affiliates did not prove as significant as it has been in the formation of domestic software industries in other countries (Giarratana et al, 2003; Giarratana et al, 2004).

The international academic background of the entrepreneurs is also moderately associated with the existence of these two groups of firm, while being an academic spin-off does not appear to be a relevant variable.

Not surprisingly, the entrepreneurs assign great importance to their networks both for the formation and early development of their companies. And since we are dealing with a knowledge-intensive sector, the predominance of relationships established to obtain knowledge and information on innovation also comes as no surprise. This may explain the dominant role of the universities in the networks. 
But customers, and more specifically the telecommunications operators and multinational affiliates, have played a crucial role in the emergence and consolidation of this group of highly innovative software for telecommunications firms in Portugal. The existence of high level engineering institutes in the country was also found to be important.

In our view, these results may help the formulation of policy measures aiming to develop this knowledge-intensive sector and may be generalized to other national and sectoral contexts. 


\section{REFERENCES}

ARAMAND, M. (2008), "Software products and services are high tech? New product development strategy for software products and services”, Technovation, 28, pp. 154-160.

BARNES, J. (1972), “Social networks”, Addison-Wesley, Phillipines.

BRUDERL, J. and PREISENDORFER, P. (1998), "Network support and success of newly founded businesses”, Small Business Economics, 10, pp. 213-225.

CAMPBELL-KELLY, M. (1995), "Development and structure of the International Software Industry, 1950-1990”, Business and Economic History, 24 (2), pp. 73-110.

CASTILLA, E., HWANG, H., GRANOVETTER, E. and GRANOVETTER, M. (2000), "Social networks in silicon valley”, in C.M. Lee, W. Miller, M.G. Hancock and H.R. Rowen (eds), “The Silicon Valley edge - a habitat for innovation and entrepreneurship”, Stanford University Press, Stanford.

CHESBROUGH, H. and ROSENBLOOM, R.S. (2002), "The role of the business model in capturing value from innovation: evidence from Xerox Corporation”s technology spin-off companies”, Industrial and Corporate Change, 11, pp. 529-555.

CLOODT, M., HAGEDOORN, J. and ROIJAKKERS, N. (2010), "Inter-firm R\&D networks in the global software industry: an overview of major trends and patterns”, Business History, 52(1), pp. 120-149.

DUBINI, P. and ALDRICH, H. (1991), "Personal and extended networks are central to entrepreneurial process”, Journal of Business Venturing, 6, pp. 305-313.

ELFRING, T. and HULSINK, W. (2003), "Networks in entrepreneurship: the case of hightechnology firms”, Small Business Economic, 21(4), pp. 409-422.

FELDMAN, M. (2001), “The entrepreneurial event revisited: firm formation in a regional context”, Industrial and Corporate Change, 10(4), pp. 861-891. 
GIARRATANA, M.S., PAGANO, A. and TORRISI, S. (2003), "Links between multinational firms and domestic firms: a comparison of the software industry in India, Ireland and Israel”, LEM Working Paper Series, 2003/2, Sant’Anna School of Advanced Studies, Laboratory of Economics and Management, Pisa.

GIARRATANA, M.S., PAGANO, A. and TORRISI, S. (2004), "The role of multinational firms in the evolution of the software industry in India, Ireland and Israel”, paper presented at the Druid Summer Conference 2004 on Industrial Dynamics, Innovation and Development, Elsinore, Denmark.

GIARRATANA, M.S. (2004), "The birth of a new industry: entry by start-ups and the drivers of firm growth - the case of the encryption software”, Research Policy, 33, pp. 787-806.

GRANOVETTER, M. (1973), “The strength of weak ties”, American Journal of Sociology, 78, pp. 1360-1380.

GRANOVETTER, M. (1982), "The strength of weak ties: a network theory revisited”, in P.V. Mardsen and Nan Lin (eds), "Social structure and network analysis”, Sage, Beverly Hills.

GRANOVETTER, M. (1985), "Economic action and social structure: the problem of embeddedness”, American Journal of Sociology, 91(3), pp. 481-510.

GREBEL, T., PYKA, A. and HANUSCH, H. (2003), “An evolutionary approach to the theory of entrepreneurship”, Industry and Innovation, 10(4), pp. 493-514.

GREVE, A. and SALAFF, J.W. (2003), “Social networks and entrepreneurship”, Entrepreneurship Theory and Practice, 28, pp. 1-22.

GRIMALDI, R. and TORRISI, S. (2001) "Codified-tacit and general-specific knowledge in the division of labour among firms: a study of the software industry”, Research Policy, 30(9), pp. 1425-1442.

HÉBERT, R. and LINK, A. (1989), "In search of the meaning of entrepreneurship”, Small Business Economics, 1, pp. 39-49. 
HITE, J. and HESTERLY, W. (2001), "The evolution of firm networks: from emergence to early growth of the firm”, Strategic Management Journal, 22, pp. 275-286.

JOHANNISSON, B. (1998), "Personal networks in emerging knowledge-based firms: spatial and functional patterns”, Entrepreneurship \& Regional Development, 10, pp. 297-312.

MALERBA, F. and TORRISI, S. (1996), "The dynamics of market structure and innovation in the western European software industry”, in D. Mowery (ed.), “The International Computer Software Industry - a comparative study of industry evolution and structure”, Oxford University Press, New York and Oxford.

MANGEMATIN, V., LEMARIÉ, S., BOISSIN, J.P., CATHERINE, D., COROLLEUR, F., CORONINI, R. and TROMMETTER, M. (2002), "Development of SMEs and heterogeneity of trajectories: the case of biotechnology in France”, Research Policy, 32(4), pp. 621-638.

MURRAY, F. (2004), “The role of inventors in knowledge transfer: sharing in the laboratory life”, Research Policy, 33(4), pp. 643-659.

MUSTAR, P., RENAUlT, M., COLOMBO, M., PIVA, E., FONTES, M., LOCKETT, A., WRIGHT, M., CLARYSSE, B. and MORAY, N. (2006), "Conceptualising the heterogeneity of research-based spin-offs: a multi-dimensional taxonomy”, Research Policy, 35(2), pp. 289-308.

OZMAN, M. (2009), "Inter-firm networks and innovation: a survey of literature”, Economics of Innovation and New Technology, 18(1), pp. 39-67.

POWELL, W. and GRODAL, S. (2005), "Networks of innovators”, in J. Fagerberg, D.C. Mowery and R.R. Nelson (eds.), “The Oxford Handbook of Innovation”, Oxford University Press, Oxford.

SALAVISA, I., VIDEIRA, P. and SANTOS, F. (2009), "Entrepreneurship and social networks in IT sectors: the case of the software industry in Portugal”, Journal of Innovation Economics, 2009/2, pp. 15-39.

SAXENIAN, A. (1994), "Regional advantage: culture and competition in Silicon Valley and Route 128”, Harvard University Press, Cambridge, MA.

SCOTT, J. (2000), “Social network analysis: a handbook”, 2nd edition, Sage Publications, London. 
SINGH, R.P. (2000), “Entrepreneurial opportunity recognition through social networks”, Garland, London.

SOUSA, C. (2008), "Redes sociais, capital social e empreendedorismo: questões teóricas e metodológicas”, Working Paper 2008/68, DINÂMIA, ISCTE-IUL, Lisbon.

STEINMUELLER, W.E. (1996), “The US software industry: an analysis and interpretive history”, in D. Mowery (ed.), "The international computer software industry - a comparative study of industry evolution and structure”, Oxford University Press, New York and Oxford.

TEECE, D.J. (1986), "Profiting from technological innovation: implications for integration, collaboration, licensing and public policy”, Research Policy, 15, pp. 285-305.

TSANG, D. (2005), “Growth of indigenous entrepreneurial software firms in cities”, Technovation, 25, pp. 1331-1336.

WELLMAN, B. (2007), "The network is personal: introduction to a special issues of Social Networks”, Social Networks, 29, pp. 349-356.

WETERINGS, A. and BOSCHMA, R. (2009), "Does spatial proximity to customers matter for innovative performance? Evidence from the Dutch software sector”, Research Policy, 38, pp. 746755.

WILLIAMSON, O. (1975), “Markets and hierarchies”, Free Press, New York. 